\title{
State of pollution of Ogosta River waters
}

\section{Състояние на замърсяването на водите на река Огоста}

\author{
Georgi Zhelezov ${ }^{\text {, Aleksey Benderev }}{ }^{2}$ \\ Георги Железов", Алексей Бендерев ${ }^{2}$ \\ ${ }^{1}$ National Institute of Geophysics, Geodesy and Geography, Bulgarian Academy of Sciences, Acad. G. Bonchev str., bl. 3 , \\ 1113 Sofia; E-mail: gzhelezov@abv.bg \\ ${ }^{2}$ Geological Institute, Bulgarian Academy of Sciences, Acad. G. Bonchev str., bl. 24, 1113 Sofia; \\ E-mail: alekseybenderev@yahoo.com
}

\begin{abstract}
The present research is related to one of the basic component of the environment - waters with study area the Ogosta river catchment. It is based on the investigation of water samples collected during field research in the river monitoring area and laboratory analysis. The research is focused on the state of the pollution and quality of the water. The results can be used in the processes of environmental optimization and realization of the strategies for sustainable development in the region.
\end{abstract}

Keywords: pollution, Ogosta River, water quality.

\section{Introduction}

The study of some of the main parameters of the leading components of the environment as water is a key element in the process of assessing the quality of the environment in each region. The present study focuses on the characterization and analysis of water quality in the Ogosta River catchment based on a series of chemical analyzes of water samples at representative control points collected during field research in the river monitoring area and laboratory analysis. The main goal of the research is to trace at a certain moment, the change of the values of basic indicators characterizing the chemical condition and the pollution along the river.

\section{Object of research}

The Ogosta River is one of the right tributaries of the Danube River, located on the territory of Bulgaria on the rivers flowing into the Danube River from Bulgarian territory. It originates from a group of springs located north of the main ridge of the Western Stara Planina (Balkan) Mountains and flows into the Danube at the 685th river kilometer at $27 \mathrm{~m}$ above sea level. Along its length - $141.1 \mathrm{~km}$ and catchment area $3157.1 \mathrm{~km}^{2}$, it ranks 17 th among the rivers of Bulgaria. The average outflow of the river at its estuary amounts to about $25.4 \mathrm{~m}^{3} / \mathrm{s}$. The average outflow of the river at its mouth is about $25.4 \mathrm{~m}^{3} / \mathrm{s}$. In its direction to the north and northeast, the Ogosta river receives a number, mainly right, tributaries - the rivers Chiprovska Ogosta, Dalgodelska Ogosta, Barzia, Botunya, Ribine and Scat.

Research related to some of the main concepts and studies, including analysis and assessment of water conditions in the research area and their optimal use are related with studies of Angelova (2001, 2008), Vasileva et al. (2008), Orehova et al. (2009, 2012), Kotsev et al. (2013), Senila et al. (2016), Stoyanova and Kotsev (2016), Stoyanova et al. (2020), Varadzhakova (2020), Yotova et al. (2021), etc.

Both natural and anthropogenic factors affect the quality of the river waters. During its course, the Ogosta River crosses major geomorphological regions in Northern Bulgaria, completely coinciding with the main tectonic units (Fig. 1).

The upper course of the river, also known as Mitrovska Ogosta, until its meeting with Chiprovska Ogosta is located in the Stara Planina (Balkan). In the same structural and geomorphological unit is located entirely Chiprovska Ogosta and most of the catchment area of Dalgodelska Ogosta. It is characterized by a typical mountainous relief, relatively narrow valleys, with an average slope of the riverbed 0.06-0.07. In the majority of the private catchment areas of the typically mountain rivers, mainly Precambrian and Paleozoic 
ingenious rocks, weakly metamorphosed and upper Paleozoic sandstones and conglomerates are revealed. Triassic succession, including limestones and dolomites, form the Elovishki karst basin in the northernmost parts. The alluvial terrace deposits form intermittent discoveries in the valley widenings of the rivers. The settlements are located in such valley widenings. The upper part of the catchments of the Chiprovska and Dalgoselska Ogosta Rivers have in the past been affected by mining activities. An accident at a tailings pond in 1966 led to serious and permanent pollution of the Chiprovska River valley and the entire Ogosta River valley with arsenic-containing fine materials.

In the range of the Forebalkan the average slope of the riverbed is relatively smaller $-0.003-0.004$. The nature of the valley is largely related to geological conditions. In the southern part of the Forebalkan Ogosta flows through a wide valley with a well-formed terrace, oriented parallel to the main tectonic structures. After the confluence of the river Burzia, the Ogosta River turns sharply to the north and the valley changes its width, but its terrace is continuous. Sedimentary rocks of Mesozoic and Neozoic age, diverse in composition, are revealed in the catchment. Several karst basins have been formed, three of which are crossed by the Ogosta River as part of the water passes underground through them. Anthropogenic pressure is associated with settlements and agriculture. The terraces of the river and the northern parts of the catchment area in the range of the Balkans are most affected by agriculture. The Ogosta River flows into the second largest dam in Bulgaria - Ogosta dam, located near the town of Montana. In the northernmost part of the catchment area of the Ogosta River it falls into the Moesian plate, which in geomorphological terms coincides with the Danube plain. Due to the flat nature, its average slope is small -0.00075 and the water flows slowly. The shaped valleys are asymmetrical with steeper eastern slopes and wide terraces. Neozoic clayey and sandy sediments are revealed in them as stripes. The inter- river spaces are covered with loess materials. The flat terrain predetermines the presence of large areas used for agricultural purposes. In the valley of the Ogosta River are located several relatively larger villages and the town of Mizia, which also has several industrial enterprises. The Scat River, which passes through the town of Mizia, flows into the Ogosta River shortly before its mouth, has a corrected bed.

\section{Materials and methods}

The first part of the study is related to the implementation of a field work and water sampling of representative key areas. Eight points along the Ogosta River and three of its tributaries were selected before flowing into the main river. Water temperature, $\mathrm{pH}$, electrical conductivity were determined on site. The second part includes laboratory tests based on photometric analysis of water samples with a photometer YSI 9500 EcoSence. Some of the main indicators of pollution have been identified, such as ammonium, nitrogen oxides, sulphates, phosphates, total N, P, Ca, Fe, Cu and $\mathrm{Zn}$. The obtained values should be compared with the requirements of Ordinance № H-4 of 14.09.2012 to characterize surface waters on water quality. The changes of these parameters along the Ogosta River and the tributaries entering the main river are analyzed. Some of these results $(\mathrm{pH}$ and $\mathrm{Cu}$ ) are illustrated in Fig. 1. Given the significantly more important anthropogenic pressure in the catchment area of the Chiprovska River, instead of the upper course of the Ogosta River, samples taken along its length are included in the prepared analyzes. The collected water samples and water research are part of the organized monitoring system in the region of the catchment area of the Ogosta River.

\section{Results and discussion}

Based on the processed results, it is established that at the time of testing the $\mathrm{pH}$ values (Fig. 1) are within the

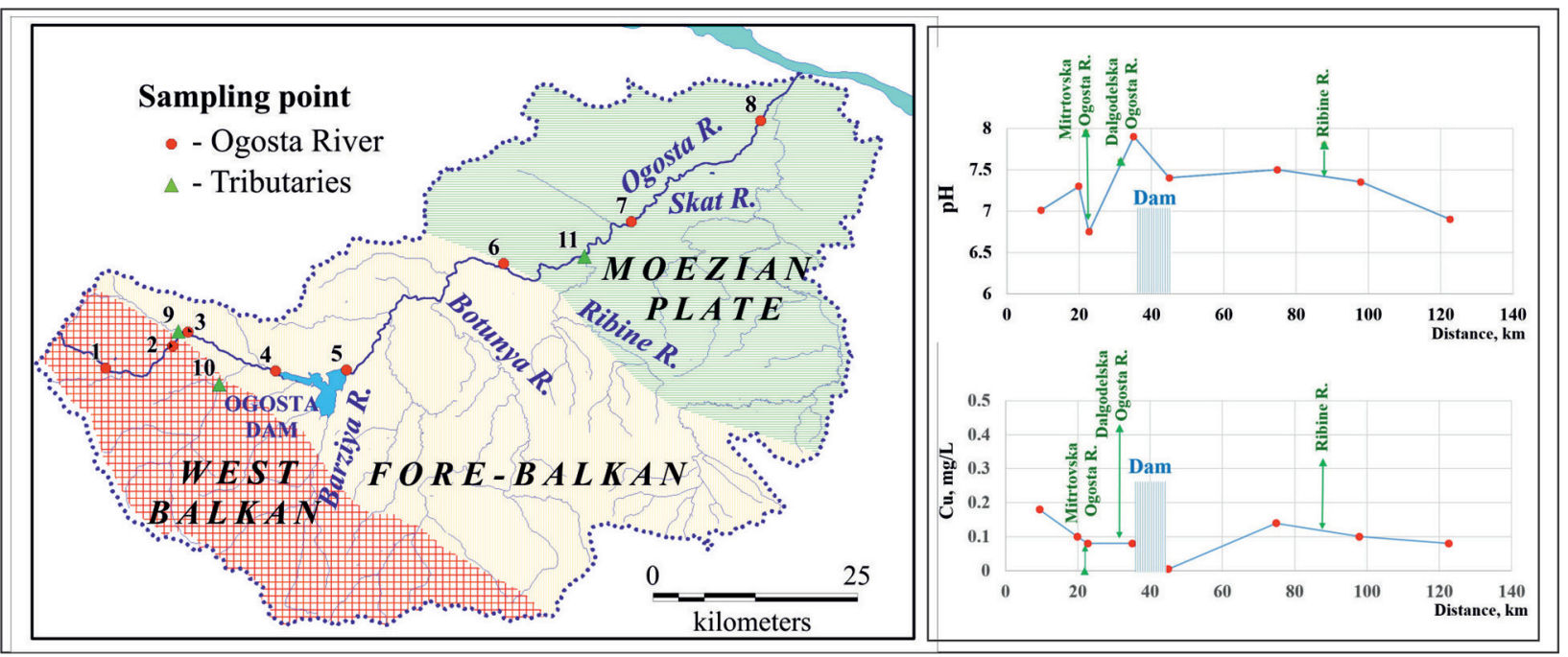

Fig. 1. Spatial model of the Ogosta river catchment with the key study points and changes in $\mathrm{pH}$ and copper content along the river 
values from 6.5 to 8.5 indicated as limit values in Ordinance № H-4 of 14.09.2012. There is a gradual increase in $\mathrm{pH}$ from the springs of the Chiprovska River to the Ogosta dam, with a sharp decrease after their collection with the Mitrovska Ogosta River. This is probably due to physicochemical processes occurring when mixing waters with different composition due to the different composition of the rocks in the two catchments. From the Ogosta dam downstream there is a slight tendency to lower the $\mathrm{pH}$. With regard to the specific electrical conductivity, a significant increase is found, as this happens faster in the upper reaches, until no changes are noticed as the mouth approaches. The reason for this is the increase of some macrocomponents, such as calcium, bicarbonates and others, for which the inflow of water formed in karst terrains is probably important, as well as the slower speed in the plain part of the river. The content of nitrogen and phosphorus compounds in river waters is not high. The lowest values are found at the entrance and exit of Ogosta dam. Regarding the assessment of their condition in accordance with the requirements of Ordinance № H-4 of 14.09.2012, it is good or very good depending on which part of the current is considered mountain or plain, given the different limit values adopted in the Ordinance. The concentration of sulphates in almost all samples taken is below $10 \mathrm{mg} / \mathrm{L}$, with the exception of the sample taken in the upper reaches of the Chiprovska River, whose catchment area has been actively affected by mining activities. This is due to the relatively higher values of copper (Fig. 1) in the same sample as in Dalgodelska Ogosta. Given the gradual deposition of copper downstream, its concentrations decrease to the Ogosta dam and increase downstream, but probably for other anthropogenic reasons.

\section{Conclusion}

The obtained results show that according to the determined indicators during the conducted testing water of Ogosta River is in relatively good condition. A number of natural and anthropogenic factors are important for the formation of its chemical composition. The natural factors, both the geological structure and the speed of the river flow are important. The role of tributaries is directly dependent on the ratio in which they mix with the main river. In this respect, the importance of Dalgodelska and Mitrovska Ogosta is relatively more important. Among the anthropogenic factors with the greatest weight for the chemical state of the river waters is the Ogosta dam. The formation of a buffer of large amounts of almost standing water intensifies the sedimentation processes and creates conditions for changing the physicochemical situation in depth. Second important aspect are the remnants of mining activities in the catchments of the Chiprovska and Dalgodelska Ogosta Rivers. In the lower reaches of the river, pollution is possible from the settlements, with their industry and agriculture. The conclusions of the conducted research on the water quality of the Ogosta River refer only to a short moment of time and serve for planning additional points and defined indicators in the planned future monitoring observations.

Acknowledgements: The scientific results in the paper are part of the work in the project "Relation of the spatial distribution of heavy metals in the soils with the morphology of contaminated river floodplains" (contract КП-06-H24/2) funded by Fund Scientific Research, Bulgaria and realized in National Institute of Geophysics, Geodesy and Geography, Bulgarian Academy of Sciences.

\section{References}

Angelova, D. 2001. Quaternary geology, geomorphology and tectonics in the Ogosta river valley system, the Danubian plain (Bulgaria). - Bull. Geol. Soc. Greece, 34, 1, 55-60; https://doi.org/10.12681/bgsg.16943.

Angelova, D. 2008. Integral environmental assessment of Ogosta River Basin (Northwestern Bulgaria). - Proc. BALWOIS 2008, Ohrid, 15 p.

Kotsev, T., A. Benderev, G. Zhelezov, C. Roman, A. Bela, M. Miclean, M. Sima, M. Dumitraşcu. 2013. Technological hazards. - In: G. Zhelezov (Ed.). Technical Guide-Hazard Assessment and Mitigation in the Danube Floodplain. Calafat-Vidin-Turnu Magurele-Nikopol Sector. Sofia, TerArt, 186-256.

Ordinance № H-4 of 14.09.2012 to Characterize Surface Waters on Water Quality. Darzhaven Vesnik No 22 of 5.03.2013 (in Bulgarian).

Orehova, T., P. Gerginov, O. Karimova. 2009. Groundwater vulnerability map for the Ogosta River Basin, Northwestern Bulgaria. - Geologica Balc., 38, 1-3, 59-67.

Orehova, T., I. Zektser, A. Benderev, O. Karimova. 2012. Evaluation of the potential groundwater recharge example of the Ogosta river basin, NW Bulgaria. - C. R. Acad. bulg. Sci., $65,10,1387-1394$.

Senila, M., T. Kotsev, E. Levei, M. Roman, V. Mladenova, Z. Cholakova, L. Senila. 2016. Preliminary investigation on arsenic fractionation in soil from Ogosta River floodplain using a seven-step extraction procedure. - Studia UBB Chemia, 61(3), 333-344.

Stoyanova, V., Ts. Kotsev, E. Tcherkezova, G. Zhelezov, N. Koleva. 2020. Land cover change in the Ogosta valley for the period 1993-2019. - Proc. Intern. Sci. Multidisciplinary GeoConference SGEM, 20, 2.2, 233-240.

Varadzhakova, D. 2020. Tourism development comparative analysis of the provinces in the Nortwest Region (Bulgaria). Intra-regional disparities. - J. Social and Economic Analysis, 1 (17).

Vasileva, T., P. Gerginov, T. Orehova. 2008. Groundwater and human pressure in the Ogosta River basin. - Proc. BALWOIS 2008, Ohrid, $10 \mathrm{p}$.

Yotova, G., S. Lazarova, V. Mihaylova, T. Venelinov. 2021. Water quality assessment of surface waters and wastewaters by traditional and ecotoxicological indicators in Ogosta River, Bulgaria. - Int. J. Bioautomation, 25, 1, 25-40; https://doi.org/10.7546/ijba.2021.25.1.000778. 